\title{
Moral Sensitivity of Young People with Intellectual Disability - Its Role in The Process of Their Education
}

\author{
Wojciech Otrebski \& Agnieszka Czusz-Sudoł
}

John Paul II Catholic University of Lublin

\begin{abstract}
According to Heller and Życiński (1980) the primary regulator of human behaviour is the system of values therefore its development should be in the centre of all educational and upbringing measures. Our focus here is on moral sensitivity understood as the ability of an individual to see social situations from the perspective of moral good and moral evil that represent values embodied in moral norms adopted by the world and internalised by humans as the principles of conduct. The main research question was the following: How morally sensitive are persons with ID and how is their sensitivity associated with the degree of intellectual disability and gender? A non-probability sample 267 of Polish residents aged $16-30$ years with mild (58.42\%) or moderate (41.58\%) intellectual disability was assembled. Men and women were almost in equal proportion. The Moral Sensitivity Inventory (MSI; Otrębski, Sudoł, 2020) has been used to measure the moral sensitivity of people with ID. It consists of 10 illustrated stories presenting typical social situations containing moral dilemmas, and an evaluation form. The tested person's task is to answer the following question "Who, in this story, did something right or wrong, and what was that?" and to indicate as many moral elements in the story and the picture as they can. The results imply that the study participants had different ability to discern moral good and moral evil. They were more sensitive to the manifestations of good and evil bad associated with Understanding one's behaviour and its impact on others (more than one-fourth of them had high scores) and less perceptive of those relating to Respect for others' property and Conformance to principles and norms. The results of the study expand the knowledge of the overall moral sensitivity of persons with intellectual disabilities.
\end{abstract}

Keywords: Intellectual Disability; Moral Sensitivity; Moral Sensitivity Measures; Process of Education.

\section{Introduction}

The main focus of the article is moral sensitivity understood as the ability of an individual to see social situations from the perspective of moral good and moral evil that represent values embodied in moral norms adopted by the world and internalised by humans as the principles of conduct. Therefore, studying moral sensitivity is basically equivalent to considering sensitivity to values. This understanding of moral sensitivity reflects its pivotal role in education and upbringing (Tsvyk \& Tsvyk, 2021).

The article is structured as follows. Its first section sets moral sensitivity in the theoretical context by explaining its role in the human life and Rest's Four Component Model (FCM) Morality (1994) adopted as a research framework. The next section characterises young adults with intellectual disabilities who participated in the study and presents findings about their moral sensitivity. In the last section, some guidelines for their education and upbringing deriving from the study are proposed.

Morality is present in everything people do. Starnawski (2011) stresses its universality, meaning that no human being is free of it and that every action or situation has some moral value - it is either morally good or morally evil. Permeates all spheres of human functioning. It also seems to have a special role in education and upbringing, which has caused Starnawski $(2011$, p. 7) to go as far as concluding that "upbringing appears to be a natural extension of morality". For 
Braun-Gałkowska (1994, p. 13), upbringing consists of efforts taken to improve a human being in such a way that they become increasingly independent and aware of the improvement process they undergo and turn it into selfimprovement.

Because human development is a complex process that transforms the entire person, upbringing, too, should take account of all dimensions of human life - from biological drives to higher spiritual needs - and seek to integrate them (Starnawski, 2011; Farber \& Metro-Roland, 2021). One of its goals is moral development that Szewczuk (1972) describes as a system of changes enabling a person to internalise and interiorise moral norms, make moral judgements of events, develop necessary moral attitudes and abilities. Some authors even use the term 'moral upbringing', which according to Magda (2000) consists of progressive stages in the interiorisation of moral norms, with each stage being necessary for the next, higher stage to occur. Moral upbringing seems to be a narrower notion falling under moral development.

Morality psychologists attach different weights to factors determining moral development depending on which theoretical approach they endorse. For instance, psychoanalysts and supporters of the social learning theory emphasise the significance of the person's milieu, especially of the role models. For cognitive psychologists, moral development is primarily influenced by the maturation of cognitive structures, but they, too, are aware of the effect of outer influences. Among those, the upbringing activity, especially of the family members, is particularly important (Gała, 1992; Jeong \& Seok, 2021).

Moral functioning is a complex process engaging many abilities that James Rest (1994) described in his Four Component Model of Morality (FCM), including moral sensitivity. The following brief description of the FCM concentrates on moral sensitivity as a key element of further discussion. In developing the FCM model he assumed that for the question "How does moral behaviour arise?" to be answered, the following components had to be considered: moral sensitivity, moral judgment, moral motivation, and moral character. All four components are necessary for moral functioning, and the absence or faultiness of any of them increases the risk of moral error arising (Rest, 1994, p. 24).

The first of them, moral sensitivity, is the main subject of this article, so it will be discussed more broadly after all other components are presented. The second component of the FCM model is moral judgment, which is understood as the ability of a person to use moral reasoning to judge whether a given situation or action is morally right. As for moral motivation, its strength decides whether, in deciding a person will give priority to morality over all other values. Lastly, moral character, which has the closest association with taking an action, is the courage or the strength of ego that one needs to decide deemed right, whatever its cost or consequences (Rest, 1994).

Moral sensitivity influences the interpretation of a situation from the perspective of moral good and moral evil. It combines the ability to determine what actions can be taken given the circumstances and the awareness that each 
action will have an effect on others (Rest, 1994). It is like "a radar" with which moral nuances can be captured. A morally sensitive person is capable of understanding that behaviours differ in moral value as choices can be morally better or worse (Mitty, 2010). The awareness that one's actions will have a bearing on others and an honest interpretation of the situation being faced are a prerequisite to choosing the response in a conscious and free manner. An appropriately high level of moral sensitivity is therefore an indispensable condition for morally right behaviour, albeit it is not sufficient.

Moral sensitivity is not something that humans are born with. Its development is influenced by various factors that according to Witkowski (1967) include the cognitive sphere, the emotional sphere, and moral experience. The cognitive sphere determines the ability to interpret situations in terms of moral good and moral evil, whose manifestations cannot be seen without appropriately developed intellectual skills (perception, attention, the ability to assess similar situations based on past experiences, to generalise them, and to subject them to critical judgment) and sufficient moral knowledge (Witkowski, 1967). Also necessary are cognitive skills enabling the creation of feasible solutions (frequently based on few clues and incomplete information) and understanding of the cause-effect chain (Bebeau \& Monson, 2008). The conclusive interpretation of a situation depends on how well it is understood and evaluated, and on one's awareness of social norms, principles, and criticism. Regarding the role of the emotional sphere in the development of moral sensitivity, it is associated with abilities humans acquire as they learn emotions, emotions associated with moral beliefs and ideals, and the emotional attitude to norms (Witkowski, 1994).

The moral development of a child starts with emotions, which are the earliest factor to guide their behaviour. A child praised by the parents reacts with satisfaction while reprimands make them unhappy and sad. As a result, a child learns which behaviour comes with an emotional reward and which has a negative emotional cost. This knowledge will be important in the future in choosing behaviour. At later stages of the developmental process, empathy and then social emotions emerge (Łuniewski, 1932; as quoted in: Witkowski, 1967, p. 96). As mentioned above, empathy (the ability to take other's perspective) is essential to moral sensitivity as it allows a person to remain "sensitive" to others feeling joy or being wronged. Positive or negative emotions evoked by a situation "help" expose its good and bad side and indicate what actions should be taken if only to avoid unpleasant experiences and be rewarded (Lukaszewski, 2007).

Moral sensitivity also depends on moral experience that influences it directly through its association with moral knowledge. A person who has been in a situation involving moral decision-making will more easily discern a similar situation in the future and will make a better decision in a shorter time. Two factors are necessary for moral experience to be formed: inner resources (e.g., the ability to learn from previous experiences) and outer influences promoting habits that will determine one's moral choices. In the development of moral sensitivity, moral experience is secondary to the cognitive and emotional spheres, but it is still indispensable (Frisancho \& Delgado, 2018; Wong, 2020).

From the above it follows that the moral sensitivity of a person depends on their personality and external factors that, according Mitty (2010), include the person's life history, culture, religion, education, emotions, and relationships with 
others. Quite naturally, such a wide diversity of factors requires multidirectional and broad research efforts. The next provides an outline of research directions on moral sensitivity in different fields of science.

Permeating the entire human existence and all spheres of human functioning, morality is a natural subject of study for researchers representing many scientific disciplines, including medicine, sociology, philosophy, business, pedagogy, and psychology. Studies of moral sensitivity in medicine usually focus on the moral dilemmas of healthcare personnel (Aleksandrova, 2008) and moral decision making (Strous, 2012). Some authors have also explored the moral sensitivity of the health centre staff, including nurses (Hojat, 2007), and of the psychiatric care staff (Reimer, 2010).

Philosophers and ethicists are primarily interested in business communities. Some studies compare the moral sensitivity of managers in different countries or continents (Oulil \& Balloun, 2009; Wimalasiri, Pavri \& Jalil, 1996; Al.-Kazemi \& Zajac, 1999; Hernandez, 2011; Roeser, 2012), others analyse the position and role of moral sensitivity in the education for managers or engineers and the processes through which they make moral decisions (Rossouw, 1994; Rabins, 1998; Hummels, 1999; Cole, Sirgy \& Bird, 2000; Sparks \& Merenski, 2000; Ruhe \& Nahser, 2001; Jacobson, 2005; Roca, 2010), and still others investigate differences in the moral sensitivity of employees at different levels of organisational hierarchy (Bone \& Corey, 2000; Buchan, 2005). There are also reports on the causes of moral sensitivity disorders in psychopathically predisposed individuals and their moral accountability (Haji, 2010), on the nature of moral reasoning (Albertzart, 2013), and on whether moral sensitivity can be developed and taught (Shawver \& Sennetti, 2009).

Most pedagogy researchers have so far concentrated on the moral sensitivity of gifted children and adolescents (Gibson, 2009; Lovecky, 2009; Roeper \& Siverman, 2009). Their studies have demonstrated an association between their levels of moral sensitivity and the levels of intelligence. The field of psychology has been interested in how moral sensitivity influences relationships between physicians or nurses and their patients (Richards et al., 2003) and in the relationship between moral sensitivity and people's tendency behave in a prosocial or antisocial manner (Gollwitzer et al., 2005). Psychologists have also studied what makes adolescents help their peers (Barnett et al., 1987).

Moral sensitivity is also analysed as an element of the functioning of people with intellectual disability (ID), but many questions in this area are yet to be resolved. To the knowledge of the authors of this article, so far only two works directly deal with this matter (Witkowski, 1967, 1994; Magda, 1999; Magda-Adamowicz \& Szmalec, 2003). Moral development of persons with ID has been studied in Poland by M. Kościelska (1984), E. Białołęcka, A. Giryński (1976), J. Pilecki (1986) and J. Kostrzewski (1981) but no comprehensive studies in this field are yet available. The cited researchers tended to analyse moral development of persons with ID only as part of their social and emotional development and did not go beyond brief references to the moral aspects of their moral and emotional functioning. 
Moral sensitivity was studied as one of the moral abilities of persons with ID over 50 years by T. Witkowski (1967) and in this century by M. Magda-Adamowicz and J. Szmalec (2003). Witkowski (1967, 1994), who pioneered research in moral sensitivity as understood in this study, compared a group adolescents with ID between the ages of 12 and 14 years with their comparative peers. His study led him to the following conclusions: (1) the moral sensitivity of adolescents with ID was lower than that of the comparative peers; (2) unlike ordinary adolescents, those with ID recognized the manifestations of moral good and moral evil but they could not explain why people behave in a good or bad way; (3) there was an association between a person's level of moral sensitivity of an individual and their intelligence, age, life experience, and emotions (Witkowski, 1967, 1994).

A somewhat different understanding of moral sensitivity than Witkowski's (1994) can be found in M. MagdaAdamowicz and J. Szmalec (2003), who They describe it as a sort of psychic tension induced by moral stimuli, which makes one sensitive to occurring moral problems and ready to solve them. (Magda-Adamowicz, Szmalec, 2003). Despite the difference between how M. Magda-Adamowicz, J. Szmalec and Witkowski understand moral sensitivity, their concepts appear to have the same core, i.e., the perception of the manifestations of moral good or moral evil and reacting to them. The studies of children aged 7-10 years and 10-11 years conducted by Magda (1999) and MagdaAdamowicz and Szmalec (2003) showed that the number of their moral reactions increased with age, indicating a rise in their moral sensitivity (Magda-Adamowicz, Szmalec, 2003). The authors also compared the level of moral sensitivity among 7-10-year-olds with ID and the comparative peers. They found that: (1) the groups differed in the level of moral sensitivity; (2) the comparative peers were more aware of moral dilemmas than the children with ID; (3) the intention to solve moral problems was comparable between the groups; (4) the development of moral sensitivity in the children with ID was primarily driven by the emotional sphere, whereas in their comparative peers, the cognitive sphere played the key role; (5) the level of moral sensitivity was closely associated with the child's age and development. The formation of moral sensitivity was determined to begin in the early education period and to be influenced by educational goals, methods and style, and didactic activities (Magda, 1999; Magda-Adamowicz \& Szmalec, 2003).

The findings mentionet above consistently confirm that the level of moral sensitivity depends on the child's age and intelligence, and that children with ID are morally less sensitive than ordinary children. Similarly, all authors report that moral sensitivity is influenced by the emotional and cognitive spheres, with Witkowski $(1967,1994)$ aditionally pointing to life experience.

Regarding the cognitive sphere, in persons with ID it is less developed, so they may be less able to see moral good and moral evil involved in social situations. As for the emotional sphere, it may or may not obstruct the formation of moral sensitivity depending on whether its development is typical or not. The influence of life experience seems more complex. While its level is to some extent associated with age because it takes time for experiences necessary for moral development to be gained, it mainly depends on external influences that persons with ID usually cannot control. The above discussion leads to the following observation. As the number of studies dealing with moral sensitivity of 
persons ID is still insufficient for definite and firm conclusions to be formulated, the need to continue research in this area is evident.

\section{Methods}

This study was undertaken with two main objectives: (1) to investigate the moral sensitivity of persons with ID using a new tool available in Poland; (2) to propose potential uses of its results in support of education for persons with ID. The main research question in our expoloratory research was the following: How morally sensitive are persons with ID and how is their moral sensitivity associated with the degree of intellectual disability and gender?

The research hypothesis tested was that: the level of moral sensitivity of the study participants would be statistically significantly associated with the degree of their intellectual disability.

\section{Sample}

A non-probability sample $(\mathrm{N}=267)$ of Polish residents aged $16-30$ years with mild $(58.42 \%)$ or moderate $(41.58 \%)$ intellectual disability was assembled. Men and women were almost in equal proportion $(52.80 \%$ and $47.20 \%$, respectively). The age group 16-30 years was selected to ensure a mix of young people who were still at school and those who completed their education and to be sure that the moral dilemmas they would be asked to resolve would be understandable and important to all of them (Table 1).

All participants were volunteers and gave oral consent to take part in the study. As part of the informed consent procedure, they were advised that their surnames would not be disclosed, and they were free to withdraw from the study at any time.

The Moral Sensitivity Inventory (MSI; Otrębski, Sudoł, 2020) has been used to measure the moral sensitivity of people with ID. It consists of a manual, a test with 10 illustrated stories presenting typical social situations containing moral dilemmas, and an evaluation form. The tested person's task is to answer the following question "Who, in this story, did something right or wrong, and what was that?" and to indicate as many moral elements in the story and the picture as they can.

The measure of the subject's moral sensitivity is the number and quality of the manifestations of moral good and moral evil identified, with quality being understood as the conspicuousness of the moral elements indicated. Scores for the most and least obvious elements range from 1 to 5, respectively. It is notable that the number of moral elements a story actually contains may be greater than that provided in the evaluation form. As a result, a person who is morally very sensitive may find new elements in the story and score extra points. 
Table 1

The demographic characteristics of the participants

\begin{tabular}{|c|c|c|}
\hline Variable & $f$ & $P$ \\
\hline \multicolumn{3}{|l|}{ Gender } \\
\hline Men & 141 & 52.80 \\
\hline Women & 126 & 47.20 \\
\hline \multicolumn{3}{|l|}{ Intellectual disability level } \\
\hline Mild & 156 & 58.42 \\
\hline Moderate & 111 & 41.58 \\
\hline \multicolumn{3}{|l|}{ Area of residence } \\
\hline Village & 108 & 40.40 \\
\hline City with up to 10,000 residents & 23 & 8.60 \\
\hline City with $10,000-50,000$ residents & 21 & 7.90 \\
\hline City with $50,000-100,000$ residents & 30 & 11.20 \\
\hline City with more than 100,000 residents & 85 & 31.80 \\
\hline \multicolumn{3}{|l|}{ Current place of living } \\
\hline Family home & 236 & 88.4 \\
\hline Institution & 3 & 1.1 \\
\hline Boarding school & 28 & 10.5 \\
\hline \multicolumn{3}{|l|}{ Current occupational status } \\
\hline Employed & 36 & 13.5 \\
\hline Social Care Centres & 19 & 7.1 \\
\hline Occupational Therapy Workshops & 100 & 37.5 \\
\hline Secondary/vocational school students & 121 & 41.9 \\
\hline
\end{tabular}

$f$-frequency; $P$ - percentage

\section{Tool - The Moral Sensitivity Inventory}

The Moral Sensitivity Inventory (MSI; Otrębski, Sudoł, 2020) has been used to measure the moral sensitivity of people with ID. It consists of a manual, a test with 10 illustrated stories presenting typical social situations containing moral dilemmas, and an evaluation form. The tested person's task is to answer the following question "Who, in this story, did something right or wrong, and what was that?" and to indicate as many moral elements in the story and the picture as they can.

The measure of the subject's moral sensitivity is the number and quality of the manifestations of moral good and moral evil identified, with quality being understood as the conspicuousness of the moral elements indicated. Scores for the 
most and least obvious elements range from 1 to 5 , respectively. It is notable that the number of moral elements a story actually contains may be greater than that provided in the evaluation form. As a result, a person who is morally very sensitive may find new elements in the story and score extra points.

In addition to measuring a person's overall moral sensitivity, the MSI also tests it according to six moral categories, namely: (1) responsibility (RES), (2) respect for the common good and the property of other people (PRO), (3) harming other people (HAR), (4) seeking and seeing the good in others (GOO), (5) conformance to principles and norms (NOR), and (6) understanding (UND). A person completing the inventory is thus assigned seven scores: a total score for overall moral sensitivity and scores for each of the six specific categories.

The MSI has satisfactory psychometric properties (Cronbach's alpha of 0.89) and uses norms developed specifically for persons with mild or moderate intellectual disability aged between 16 and 30. It shows that persons with mild intellectual disability have a higher level of moral sensitivity than those with moderate disability, which confirms its theoretical validity (Witkowski \& Otrębski et al., 2015).

\section{Analysis of Group Data}

The study group was characterised by means of basic descriptive statistics, means (M), and standard deviations (SD). Using Student's t-test and Pearson's $c h i^{2}$ test, the composition of the group in terms of the degrees of disability and gender of the participants was established.

\section{Moral Sensitivity of Persons with Intellectual Disability}

The analysis of the moral sensitivity of persons with ID will first be performed for all participants and then for the subgroups created according to their degree of disability (Mild - ID-Mi, moderate - ID-Mo) and gender.

\section{Moral Sensitivity of The Study Group}

Participants scored on overall moral sensitivity from 8 to 165 pts $(M=50.53$ and $\mathrm{SD}=24.91$. The highest and lowest mean scores related to moral categories Seeking and seeing the good in others and Respect for the common good and the property of other people, respectively (Table 2).

Regarding participants' scores on overall moral sensitivity, most of them (46.82\%) had moderate scores, almost $30 \%$ had low scores, and nearly one-fourth had high scores. With regard to particular moral categories, the scores of most participants were moderate. Depending on the category, from 18.35 to $26.97 \%$ of the participants achieved high scores and from 28.46 to $41.57 \%$ had low scores. Interestingly, participants with low scores outnumbered those with high scores (Table 3). 
Table 2

Moral sensitivity in the group (overall and by category)

\begin{tabular}{cccccc}
\hline Variable & & $M$ & $S D$ & Min & Max \\
\hline \multirow{2}{*}{ TOTAL } & & 50.53 & 24.91 & 8 & 165 \\
& RES & 8.46 & 5.27 & 0 & 27 \\
& GOO & 12.62 & 9.01 & 1 & 54 \\
Moral categories & PRO & 5.42 & 2.80 & 0 & 14 \\
& HAR & 9.08 & 3.97 & 0 & 23 \\
& NOR & 8.16 & 5.46 & 0 & 32 \\
& UND & 6.79 & 5.95 & 0 & 28 \\
\hline
\end{tabular}

$M$ - mean; SD - standard deviation; Min - the lowest score; Max - the highest score; TOTAL - total score; RES - responsibility; $G O O$ - seeking and seeing the good in others; PRO - respect for the common good and the property of other people; HAR harming other people; NOR - conformance to principles and norms; UND - understanding.

The numbers imply that the study participants had different ability to discern moral good and moral evil. They were more sensitive to the manifestations of good and evil bad associated with Understanding one's behaviour and its impact on others (UND) (more than one-fourth of them had high scores) and less perceptive of those relating to Respect for others' property (HAR) and Conformance to principles and norms (NOR) (Table 3).

Table 3

Moral sensitivity of the study participants by moral category

\begin{tabular}{cccccccccccccccc}
\hline $\begin{array}{c}\text { Moral } \\
\text { category }\end{array}$ & TOTAL & \multicolumn{2}{c}{ RES } & \multicolumn{2}{c}{ GOO } & PRO & HAR & NOR & & UND \\
\hline $\begin{array}{c}\text { Level of } \\
\text { moral }\end{array}$ & $f$ & $P$ & $f$ & $P$ & $f$ & $P$ & $f$ & $P$ & $f$ & $P$ & $f$ & $P$ & $f$ & $P$ \\
$\begin{array}{c}\text { sensitivity } \\
\text { High }\end{array}$ & 66 & 24.72 & 59 & 22.10 & 57 & 21.35 & 49 & 18.35 & 49 & 18.35 & 65 & 24.34 & 72 & 26.97 \\
Moderate & 125 & 46.82 & 112 & 41.95 & 124 & 46.44 & 107 & 40.07 & 116 & 43.45 & 93 & 34.83 & 92 & 34.46 \\
Low & 76 & 28.46 & 96 & 35.96 & 86 & 32.21 & 111 & 41.57 & 102 & 38.20 & 109 & 40.82 & 103 & 38.58 \\
\hline
\end{tabular}

$f$ - number; $P$ - percentage; TOTAL - total score; $R E S$ - responsibility; $G O O$ - seeking and seeing the good in others; $P R O$ respect for the common good and the property of other people; HAR - harming other people; NOR - conformance to principles and norms; $U N D$ - understanding.

\section{Moral Sensitivity and The Degree of Intellectual Disability}

Participants with ID-Mi were capable of recognising a greater number of the manifestations of moral good and evil in social situations than those with ID-Mo, as indicated by their scores on overall moral sensitivity ranging from 12 to 165 pts $(\mathrm{M}=56.37$ and $\mathrm{SD}=24.92)$ and from 8 to 140 pts $(\mathrm{M}=42.33$ and $\mathrm{SD}=22.58)$, respectively. The difference 
between the mean scores of the two subgroups $(M=56.37$ vs. $M=42.33)$ is statistically significant $(p \leq 0.001)$ and implies an association between the level of moral sensitivity and the degree of intellectual disability (Table 4).

\section{Table 4}

Overall moral sensitivity of the participants by degree of intellectual disability

\begin{tabular}{cccccccc}
\hline Degree of ID & $M$ & Min & $\operatorname{Max}$ & $S D$ & $t$ & $p$ & $d$ \\
\hline Mild (ID-Mi) & 56.37 & 12.00 & 165.00 & 24.92 & \multirow{2}{*}{ (I.731 } & 0.001 & 0.590 \\
Moderate (ID-Mo) & 42.33 & 8.00 & 140.00 & 22.58 & & &
\end{tabular}

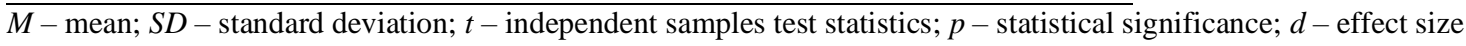

The analysis of the mean scores by moral category, too, shows that the ID-Mi group always scored higher on them than the ID-Mo group. All differences between the two subgroups are statistically significant and have an average effect size (Table 5).

\section{Table 5}

Moral sensitivity of the participants by moral category and degree of intellectual disability

\begin{tabular}{cccccccc}
\hline & \multicolumn{3}{c}{ Degree of disability } & \multicolumn{3}{c}{ Student t-test } \\
Moral categories & \multicolumn{2}{c}{ Mild } & \multicolumn{4}{c}{$M$} & \multicolumn{3}{c}{ Moderate } & & \\
& $M$ & $S D$ & $M$ & $S D$ & $T$ & & $d$ \\
RES & 9.45 & 5.33 & 7.07 & 4.88 & 3.719 & 0.001 & 0.466 \\
GOO & 14.15 & 9.33 & 10.47 & 8.10 & 3.352 & 0.001 & 0.421 \\
PRO & 5.92 & 2.74 & 4.71 & 2.74 & 3.555 & 0.001 & 0.442 \\
HAR & 9.56 & 3.47 & 8.41 & 4.51 & 2.357 & 0.019 & 0.286 \\
NOR & 9.49 & 5.47 & 6.30 & 4.89 & 4.912 & 0.001 & 0.615 \\
UND & 7.79 & 6.03 & 5.38 & 5.57 & 3.331 & 0.001 & 0.415 \\
\hline
\end{tabular}

$M$ - mean; $S D$ - standard deviation; $t$ - independent samples test statistics; $p$ - statistical significance; $d$ - effect size; $R E S$ responsibility; $G O O$ - seeking and seeing the good in others; $P R O$ - respect for the common good and the property of other people; $H A R$ - harming other people; NOR - conformance to principles and norms; $U N D$ - understanding.

Participants with ID-Mi more easily recognised moral good and moral evil in situations concerning responsibility, seeking and seeing the good in others, respect for the property of other, harming other people, conformance to principles and norms, and realizing the consequences of one's actions (Table 5).

The data also show that while most participants in both subgroups (44.87\% in the ID-Mi and 49.55\% in the ID-Mo) had moderate scores on overall moral sensitivity, the subgroups differed in the percentages of participants with high and low scores. In the ID-Mi subgroup, there were more high scores than low scores on overall moral sensitivity 
( $34.66 \%$ vs. $20.51 \%$ ), whereas in the ID-Mo subgroup, it was the other way round (10.81\% vs. $39.64 \%)$. It is likely that the differences had to do with different cognitive functioning of persons with ID (Table 6).

The distribution of participants' high, moderate, and low scores on moral categories depended on the moral category and the degree of their intellectual disability. In the ID-Mi subgroup, most participants (from $35.90 \%$ to $54.49 \%$ ) had moderate scores, somewhat fewer (from $22.44 \%$ to $33.33 \%$ ) had high scores, and the smallest group (from $16.67 \%$ to $34.62 \%$ ) had low scores. A reverse situation occurred in the ID-Mo subgroup, where low, moderate and high scores were achieved by between $39.64 \%$ and $54.95 \%, 27.93 \%$ and $48.65 \%$, and $11.71 \%$ to $20.72 \%$ of the participants. All differences between the distributions of low, moderate, and high scores are statistically significant (Table 6).

\section{Table 6}

Participants' moral sensitivity by degree of intellectual disability

\begin{tabular}{|c|c|c|c|c|c|c|c|}
\hline \multirow{2}{*}{\multicolumn{2}{|c|}{ Level of moral sensitivity }} & \multicolumn{4}{|c|}{ Intellectual disability } & \multirow{2}{*}{\multicolumn{2}{|c|}{ Pearson's $c h i^{2}$ test }} \\
\hline & & \multicolumn{2}{|c|}{ Mild } & \multicolumn{2}{|c|}{ Moderate } & & \\
\hline & & $f$ & $P$ & $f$ & $P$ & $c h i^{2}$ & $p$ \\
\hline & High & 54 & 34.62 & 12 & 10.81 & & \\
\hline \multirow{3}{*}{ TOTAL } & Moderate & 70 & 44.87 & 55 & 49.55 & 22.50 & 0.001 \\
\hline & Low & 32 & 20.51 & 44 & 39.64 & & \\
\hline & High & 44 & 28.21 & 15 & 13.51 & & \\
\hline \multirow[t]{3}{*}{ RES } & Moderate & 68 & 43.59 & 44 & 39.64 & 12.84 & 0.002 \\
\hline & Low & 44 & 28.21 & 52 & 46.85 & & \\
\hline & High & 35 & 22.44 & 14 & 12.61 & & \\
\hline \multirow[t]{3}{*}{ GOO } & Moderate & 67 & 42.95 & 40 & 36.04 & 8.55 & 0.014 \\
\hline & Low & 54 & 34.62 & 57 & 51.35 & & \\
\hline & High & 26 & 28.85 & 23 & 20.72 & & \\
\hline \multirow[t]{3}{*}{ PRO } & Moderate & 85 & 54.49 & 31 & 27.93 & 19.71 & 0.001 \\
\hline & Low & 45 & 16.67 & 57 & 51.35 & & \\
\hline & High & 44 & 26.92 & 13 & 11.71 & & \\
\hline \multirow[t]{3}{*}{ HAR } & Moderate & 70 & 44.87 & 54 & 48.65 & 11.72 & 0.003 \\
\hline & Low & 42 & 28.21 & 44 & 39.64 & & \\
\hline & High & 52 & 33.33 & 13 & 11.71 & & \\
\hline \multirow[t]{3}{*}{ NOR } & Moderate & 56 & 35.90 & 37 & 33.33 & 21.87 & 0.001 \\
\hline & Low & 48 & 30.77 & 61 & 54.95 & & \\
\hline & High & 49 & 31.41 & 23 & 20.72 & & \\
\hline \multirow[t]{2}{*}{ UND } & Moderate & 60 & 38.46 & 32 & 28.83 & 11.44 & 0.003 \\
\hline & Low & 47 & 30.13 & 56 & 50.45 & & \\
\hline
\end{tabular}

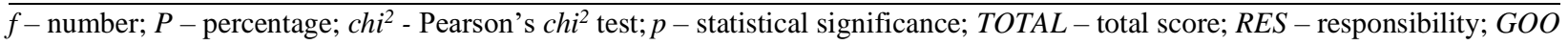
- seeking and seeing the good in others; $P R O$ - respect for the common good and the property of other people; HAR - harming other people; $N O R$ - conformance to principles and norms; $U N D$ - understanding.

According to these results, persons with mild intellectual disability recognise more manifestations of moral good and evil in social situations, meaning that they are morally more sensitive than those with moderate intellectual disability.

\section{Moral Sensitivity of The Participants by Gender}

Gender did not cause major differences in the study participants' scores on overall moral sensitivity. Men scored from 8 to 165 pts $(\mathrm{M}=50.41, \mathrm{SD}=20.03)$ and women from 12 to $140 \mathrm{pts}(\mathrm{M}=50.67$ ( $\mathrm{SD}=26.96)$. The difference between the 
scores is statistically not significant ( $\mathrm{t}=-0.083 ; p=0.93)$, indicating that the level of moral sensitivity was comparable between men and women (Table 7). The differences between their scores on particular moral categories were not significant, either (Table 8), implying that men and women with intellectual disabilities react with similar sensitivity to moral elements contained in various social situations.

Most men and women in the study achieved moderate scores on overall moral sensitivity (TOTAL) and its categories. However, depending on the moral category, more men than women, or vice versa, had high or low scores. Women proved to be slightly more sensitive to the moral aspects of respect for the property of other people (PRO; 23.02\% scored high), harming other people (HAR; 20.63\%), conformance to principles and norms (NOR; 30.16\%) and seeing the impact of one's actions (UND; 30.16\%). On the other hand, men more easily perceived the moral aspects of seeking and seeing the good in others (GOO, 23.40\% achieved high scores). Overall, though, the differences between men and women were very subtle except for one moral category (conformance to principles and norms) where their scores were significantly different (Table 9). The conclusion from this analysis is that men and women with intellectual disabilities are comparable in respect of moral sensitivity, but high sensitivity is more common among the former.

\section{Table 7}

Participants' overall moral sensitivity by gender

\begin{tabular}{cccccccc}
\hline Gender & M & Min. & Max. & SD & $t$ & $P$ & $d$ \\
\hline Women & 50.41 & 8 & 165 & 20.03 & -0.083 & 0.93 & - \\
Men & 50.67 & 12 & 140 & 26.96 & & & \\
$M$ - mean; $S D-$ standard deviation; $t$ - independent samples test statistics; $p$ - statistical significance; $d$ - effect size
\end{tabular}

\section{Table 8}

Participants' moral sensitivity by moral category and gender

\begin{tabular}{cccccccc}
\hline \multirow{2}{*}{ Moral category } & \multicolumn{2}{c}{ Women } & \multicolumn{2}{c}{ Men } & \multicolumn{3}{c}{ Student's t-test } \\
\cline { 2 - 8 } & $M$ & $S D$ & $M$ & $S D$ & $t$ & $p$ & $d$ \\
\cline { 2 - 8 } RES & 8.21 & 5.23 & 8.68 & 5.13 & 0.722 & 0.47 & - \\
GOO & 11.97 & 8.87 & 13.20 & 9.12 & 1.115 & 0.27 & - \\
PRO & 5.71 & 2.91 & 5.16 & 2.69 & -1.585 & 0.11 & - \\
HAR & 9.07 & 4.26 & 9.09 & 3.71 & 0.028 & 0.98 & - \\
NOR & 8.52 & 5.19 & 7.85 & 5.03 & -0.993 & 0.32 & - \\
UND & 7.19 & 6.52 & 6.43 & 5.39 & -1.039 & 0.30 & - \\
\hline
\end{tabular}

$M$ - mean; $S D$ - standard deviation; $t$-independent samples test statistics; $p$ - statistical significance; $d$ - effect size; TOTALtotal score; RES - responsibility; GOO - seeking and seeing the good in others; $P R O$ - respect for the common good and the property of other people; HAR - harming other people; $N O R$ - conformance to principles and norms; $U N D$ - understanding.

Men and women were also analysed for differences in moral sensitivity taking account of their intellectual disability. While gender alone did not considerably differentiate their moral sensitivity, single differences were found between men and women in the subgroups with the same degree of ID. In the ID-Mi subgroup, the overall moral sensitivity (TOTAL) of men and women was not significantly different, likewise their sensitivity to moral elements contained in the majority of moral categories excluding seeking and seeing the good in others (GOO; $\mathrm{t}=2.117, p=0.04$ ) (Table 10), 
in which case more women with ID-Mi than men recognised moral elements in social situations where others experienced good things (Table 10).

Men and women in the ID-Mo subgroup were not significantly different from each other in either overall moral sensitivity or most moral categories. The only exception was conformance to principles and principles (NOR; $\mathrm{t}=-$ 2.264, $p=0.003$ ) (Table 11), where more women than men identified the elements of moral good and moral evil when moral principles and norms were respected or breached (Table 11).

\section{Table 9}

Participants' moral sensitivity by gender

\begin{tabular}{|c|c|c|c|c|c|c|c|}
\hline \multirow{2}{*}{\multicolumn{2}{|c|}{ Level of moral sensitivity }} & \multicolumn{4}{|c|}{ Gender } & \multirow{2}{*}{\multicolumn{2}{|c|}{ Pearson's $c h i^{2}$ test }} \\
\hline & & \multicolumn{2}{|c|}{ Women } & \multicolumn{2}{|c|}{ Men } & & \\
\hline & & $f$ & $P$ & $f$ & $P$ & $c h i^{2}$ & $p$ \\
\hline & High & 33 & 26.19 & 33 & 23.40 & & \\
\hline \multirow[t]{3}{*}{ TOTAL } & Moderate & 54 & 42.86 & 71 & 50.35 & 1.527 & 0.46 \\
\hline & Low & 39 & 30.95 & 37 & 26.24 & & \\
\hline & High & 28 & 22.22 & 31 & 21.99 & & \\
\hline \multirow[t]{3}{*}{ RES } & Moderate & 49 & 38.89 & 63 & 44.68 & 1.105 & 0.58 \\
\hline & Low & 49 & 38.89 & 47 & 33.33 & & \\
\hline & High & 29 & 23.02 & 20 & 14.18 & & \\
\hline \multirow[t]{3}{*}{ PRO } & Moderate & 48 & 38.10 & 59 & 41.84 & 3.475 & 0.18 \\
\hline & Low & 49 & 38.89 & 62 & 43.97 & & \\
\hline & High & 26 & 20.63 & 23 & 16.31 & & \\
\hline \multirow[t]{3}{*}{ HAR } & Moderate & 50 & 39.68 & 66 & 46.81 & 1.592 & 0.45 \\
\hline & Low & 50 & 39.68 & 52 & 36.88 & & \\
\hline & High & 24 & 19.05 & 33 & 23.40 & & \\
\hline \multirow[t]{3}{*}{ GOO } & Moderate & 54 & 42.86 & 70 & 49.65 & 3.818 & 0.15 \\
\hline & Low & 48 & 38.10 & 38 & 26.95 & & \\
\hline & High & 38 & 30.16 & 27 & 19.15 & & \\
\hline \multirow[t]{3}{*}{ NOR } & Moderate & 35 & 27.78 & 58 & 41.13 & 6.811 & 0.03 \\
\hline & Low & 53 & 42.06 & 56 & 39.72 & & \\
\hline & High & 38 & 30.16 & 34 & 24.11 & & \\
\hline \multirow[t]{2}{*}{ UND } & Moderate & 38 & 30.16 & 54 & 38.30 & 2.257 & 0.32 \\
\hline & Low & 50 & 39.68 & 53 & 37.59 & & \\
\hline
\end{tabular}

The distributions of high, moderate, and low scores on overall moral sensitivity and its categories in Table 12 are not significantly different between men and women with ID-Mi. Accordingly, their moral sensitivity was similar.

Women and men with ID-Mo scored differently on overall moral sensitivity (TOTAL; chi $^{2}=5.950, p=0.05$ ) and on the moral category seeking and seeing the good in others (GOO; $\left.\mathrm{chi}^{2}=12.431, p=0.002\right)$. More women with ID-Mo than men had low scores (43.40\%) and high scores (16.98\%), and fewer had moderate scores (39.62\%). In contrast, among men with ID-Mo, more participants had moderate scores (58.62\%) and fewer had low scores (36.21\%) and high scores (5.17\%). Low scores on the moral category seeking and seeing the good in others (PRO) were statistically significantly 
more frequent among women than among men (49.06\% vs.31.03\%), but twice more men had moderate scores $(63.79 \%$ vs. $32.08 \%$ ), and almost four times as many had high scores (18.87\% vs. 5.17\%). Therefore, women with ID-Mo were more likely than men to demonstrate high or low sensitivity to the moral elements of situations in which others experienced good things. Most men were moderately sensitive to them (Table 13).

Table 10

Moral sensitivity of participants in the ID-Mi group by gender

\begin{tabular}{|c|c|c|c|c|c|c|c|}
\hline \multirow{3}{*}{$\begin{array}{c}\text { Moral } \\
\text { category }\end{array}$} & \multicolumn{4}{|c|}{ Gender } & \multirow{2}{*}{\multicolumn{3}{|c|}{ Student's t-test }} \\
\hline & \multicolumn{2}{|c|}{ Women } & \multicolumn{2}{|c|}{ Men } & & & \\
\hline & $\mathrm{M}$ & SD & $\mathrm{M}$ & SD & $\mathrm{t}$ & $\mathrm{p}$ & Cohen's d \\
\hline WO & 55.10 & 26.62 & 57.48 & 23.43 & 0.595 & 0.55 & - \\
\hline RES & 9.62 & 5.29 & 9.61 & 5.38 & 0.413 & 0.68 & - \\
\hline GOO & 12.48 & 8.30 & 15.61 & 9.97 & 2.117 & 0.04 & 0.341 \\
\hline PRO & 6.37 & 2.82 & 5.53 & 2.63 & -1.924 & 0.06 & - \\
\hline HAR & 9.59 & 3.68 & 9.53 & 3.30 & -0.105 & 0.92 & - \\
\hline NOR & 9.34 & 5.20 & 9.63 & 5.08 & 0.322 & 0.75 & - \\
\hline UND & 8.05 & 6.71 & 7.57 & 5.39 & -0.504 & 0.61 & - \\
\hline
\end{tabular}

$M$ - mean; $S D$ - standard deviation; $t$ - independent samples test statistics; $p$ - statistical significance; $d$ - effect size; TOTAL total score; $R E S$ - responsibility; $G O O$ - seeking and seeing the good in others; $P R O$ - respect for the common good and the property of other people; $H A R$ - harming other people; $N O R$ - conformance to principles and norms; $U N D$ - understanding.

\section{Table 11}

Moral sensitivity of participants in the ID-Mo group by gender

\begin{tabular}{|c|c|c|c|c|c|c|c|}
\hline \multirow{3}{*}{$\begin{array}{c}\text { Moral } \\
\text { categories }\end{array}$} & \multicolumn{4}{|c|}{ Gender } & \multirow{2}{*}{\multicolumn{3}{|c|}{ Student's t-test }} \\
\hline & \multicolumn{2}{|c|}{ Women } & \multicolumn{2}{|c|}{ Men } & & & \\
\hline & $M$ & $S D$ & $M$ & $S D$ & $t$ & $p$ & $d$ \\
\hline WO & 44.57 & 26.46 & 40.29 & 18.34 & -0.996 & 0.32 & - \\
\hline RES & 6.77 & 4.82 & 7.34 & 4.95 & 0.615 & 0.54 & - \\
\hline GOO & 11.26 & 9.65 & 9.74 & 6.36 & -0.990 & 0.32 & - \\
\hline PRO & 4.79 & 2.80 & 4.64 & 2.71 & -0.295 & 0.77 & - \\
\hline HAR & 8.36 & 4.89 & 8.45 & 4.18 & 0.104 & 0.92 & - \\
\hline NOR & 7.38 & 5.77 & 5.31 & 3.71 & -2.264 & 0.03 & 0.427 \\
\hline UND & 6.00 & 6.12 & 4.81 & 5.00 & -1.126 & 0.26 & - \\
\hline
\end{tabular}

$M$ - mean; $S D$ - standard deviation; $t$ - independent samples test statistics; $p$ - statistical significance; $d$ - effect size; TOTAL total score; RES - responsibility; $G O O$ - seeking and seeing the good in others; $P R O$ - respect for the common good and the property of other people; HAR - harming other people; NOR - conformance to principles and norms; UND - understanding. 
Table 12

Moral sensitivity of participants in the ID-Mi group by gender

\begin{tabular}{|c|c|c|c|c|c|c|c|}
\hline \multirow{2}{*}{\multicolumn{2}{|c|}{ Level of moral sensitivity }} & \multicolumn{4}{|c|}{ Gender } & \multirow{2}{*}{\multicolumn{2}{|c|}{ Pearson's $c h i^{2}$}} \\
\hline & & \multicolumn{2}{|c|}{ Gender } & \multicolumn{2}{|c|}{ Men } & & \\
\hline & & $f$ & $P$ & $f$ & $P$ & $c h i^{2}$ & $p$ \\
\hline & High & 24 & 32.88 & 30 & 36.14 & & \\
\hline \multirow[t]{3}{*}{ TOTAL } & Moderate & 33 & 45.21 & 37 & 44.58 & 0.255 & 0.88 \\
\hline & Low & 16 & 21.92 & 16 & 19.28 & & \\
\hline & High & 21 & 28.77 & 23 & 27.71 & & \\
\hline \multirow[t]{3}{*}{ RES } & Moderate & 31 & 42.47 & 37 & 44.58 & 0.070 & 0.96 \\
\hline & Low & 21 & 28.77 & 23 & 27.71 & & \\
\hline & High & 14 & 19.18 & 30 & 36.14 & & \\
\hline \multirow[t]{3}{*}{ GOO } & Moderate & 37 & 50.68 & 33 & 39.76 & 5.524 & 0.06 \\
\hline & Low & 22 & 30.14 & 20 & 24.10 & & \\
\hline & High & 22 & 30.14 & 13 & 15.66 & & \\
\hline \multirow[t]{3}{*}{ PRO } & Moderate & 29 & 39.73 & 38 & 45.78 & 4.754 & 0.09 \\
\hline & Low & 22 & 30.14 & 32 & 38.55 & & \\
\hline & High & 13 & 17.81 & 13 & 15.66 & & \\
\hline \multirow[t]{3}{*}{ HAR } & Moderate & 38 & 52.05 & 47 & 56.63 & 0,336 & 0,846 \\
\hline & Low & 22 & 30.14 & 23 & 27.71 & & \\
\hline & High & 28 & 38.36 & 24 & 28.92 & & \\
\hline \multirow[t]{3}{*}{ NOR } & Moderate & 19 & 26.03 & 37 & 44.58 & 5,810 & 0,06 \\
\hline & Low & 26 & 35.62 & 22 & 26.51 & & \\
\hline & High & 24 & 32.88 & 25 & 30.12 & & \\
\hline \multirow[t]{2}{*}{ UND } & Moderate & 24 & 32.88 & 36 & 43.37 & 1,979 & 0,37 \\
\hline & Low & 25 & 34.25 & 22 & 26.51 & & \\
\hline
\end{tabular}

\section{Discussions}

The results of the study expand the knowledge of the overall moral sensitivity of persons with intellectual disabilities, as well as of their sensitivity to specific manifestations of moral good and moral evil in social situations. They show that moral sensitivity in the study group was mostly moderate and that participants with ID-Mi demonstrated high or low moral sensitivity more frequently than those with ID-Mo.

A plausible reason why the former had higher scores on overall moral sensitivity and all moral categories is better cognitive functioning of persons with ID-Mi (Wyczesany, 2002; Shalock et al. 2012). Other authors (Czusz, Otrębski, 2013) made a similar observation, reporting higher moral sensitivity in teenagers and young adults (aged 16-32 years) with ID-Mi compared with their peers with ID-Mo. They also noted in their study that the percentage of participants with ID-Mi who scored low on moral sensitivity was greater than those with ID-Mo, which has also been confirmed by this study. Therefore, both studies lead to the conclusion that the moral sensitivity of adolescents and adults with intellectual disability is significantly determined by its degree and that wrażliwość moralna jest związana z poziomem rozwoju umysłowego już od wieku dziecięcego. 


\section{Table 13}

Moral sensitivity of participants with ID-Mo by gender

\begin{tabular}{|c|c|c|c|c|c|c|c|}
\hline \multirow{2}{*}{\multicolumn{2}{|c|}{ Level of moral sensitivity }} & \multicolumn{4}{|c|}{ Gender } & \multirow{2}{*}{\multicolumn{2}{|c|}{ Pearson's $c h i^{2}$}} \\
\hline & & \multicolumn{2}{|c|}{ Women } & \multicolumn{2}{|c|}{ Men } & & \\
\hline & & $f$ & $P$ & $f$ & $P$ & $c h i^{2}$ & $p$ \\
\hline & High & 9 & 16.98 & 3 & 5.17 & & \\
\hline \multirow[t]{3}{*}{ TOTAL } & Moderate & 21 & 39.62 & 34 & 58.62 & 5.950 & 0.05 \\
\hline & Low & 23 & 43.40 & 21 & 36.21 & & \\
\hline & High & 7 & 13.21 & 8 & 13.79 & & \\
\hline \multirow{3}{*}{ RES } & Moderate & 18 & 33.96 & 26 & 44.83 & 1.607 & 0.44 \\
\hline & Low & 28 & 52.83 & 24 & 41.38 & & \\
\hline & High & 10 & 18.87 & 3 & 5.17 & & \\
\hline \multirow[t]{3}{*}{ GOO } & Moderate & 17 & 32.08 & 37 & 63.79 & 12.431 & 0.002 \\
\hline & Low & 26 & 49.06 & 18 & 31.03 & & \\
\hline & High & 7 & 13.21 & 7 & 12.07 & & \\
\hline \multirow[t]{3}{*}{ PRO } & Moderate & 19 & 35.85 & 21 & 36.21 & 0.033 & 0.98 \\
\hline & Low & 27 & 50.94 & 30 & 51.72 & & \\
\hline & High & 13 & 24.53 & 10 & 17.24 & & \\
\hline \multirow[t]{3}{*}{ HAR } & Moderate & 12 & 22.64 & 19 & 32.76 & 1.768 & 0.413 \\
\hline & Low & 28 & 52.83 & 29 & 50.00 & & \\
\hline & High & 10 & 18.87 & 3 & 5.17 & & \\
\hline \multirow[t]{3}{*}{ NOR } & Moderate & 16 & 30.19 & 21 & 36.21 & 5.033 & 0.08 \\
\hline & Low & 27 & 50.94 & 34 & 58.62 & & \\
\hline & High & 14 & 26.42 & 9 & 15.52 & & \\
\hline \multirow[t]{2}{*}{ UND } & Moderate & 14 & 26.42 & 18 & 31.03 & 2,009 & 0,37 \\
\hline & Low & 25 & 47.17 & 31 & 53.45 & & \\
\hline
\end{tabular}

In this study, gender was not found to differentiate moral sensitivity measured for the entire group or between participants with ID-Mi and ID-Mo, similarly to Czusz \& Otrębski (2013). In single instances, however, women showed greater moral sensitivity than men. Women with ID-Mi more easily discerned moral good and moral evil when other people experienced good things, and those with ID-Mo when moral principles and norms were respected or breached. These findings correspond to the results of metaanalysis, which have corroborated significant, betweengender differences in the moral sensitivity of ordinary subjects and a higher moral sensitivity of women (You, Maeda \& Bebeau, 2011).

The results of our research expand the knowledge of the moral functioning of persons with intellectual disability but have some limitations. For instance, as the participants' understanding of the instructions and illustrative stories was not controlled, it is not possible to state unambiguously whether the level of disability was the only factor that influenced their moral sensitivity. The role of emotional functioning and life experience were not investigated, either. This limitation can be removed in future research by conducting personal in-depth interviews with the participants.

Despite the limitations of the study, its results seem useful as practical support for educational and upbringing processes that also influence moral development by facilitating the internalisation of norms and modelling human 
behaviour (Starnawski, 2011). Education for moral sensitivity is certainly important, given that in Rest's theory of morality (1994), it is the first of the four components necessary for the effective moral functioning of humans. If so, it should concentrate on developing the qualities that people need to be morally sensitive, such as empathy and the awareness of one's and others' emotions, especially of the signs that someone is people being wronged. Teaching people to take others' perspective and understand the impact of there is also useful.

In developing the moral sensitivity of young people with intellectual disabilities, measures developing their theory of mind can be beneficial, likewise opportunities to experience and discuss new social situations, activities sensitizing them to moral good and moral evil contained in them, and helping them understand that their actions will have consequences for them and other people. All this could help them accumulate life experience that plays a major role in the development of moral sensitivity. As males with mild intellectual disabilities are reported to be morally less sensitive to moral good and moral evil in situations requiring conformance to principles and norms, this aspect should be specifically addressed in their upbringing and moral education. It also seems necessary that programmes aimed to develop the moral sensitivity of persons with intellectual disabilities make use of methods and techniques appropriate for their gender and the degree of disability.

Summing up, efforts fostering the moral development of people of all intellectual abilities are important because morality influences all aspects of human functioning. People with intellectual disabilities seem to deserve special attention in this regard because attempts to help them overcome the consequences of their impaired cognitive abilities have so far frequently been made at the cost of other spheres of their functioning (Frisancho \& Delgado, 2018; Jing \& Suting, 2020; Wong, 2020; Farber \& Metro-Roland, 2021).

\section{References}

Al-Kazemi, A.A., Zajac, G. (1999). Ethics Sensitivity and Awareness Within Organizations in Kuwait: An Empirical Exploration of Espoused Theory and Theory-in-Use. Journal of Business Ethics, 20, 4, 353 361.

Albertzart, M. (2013). Principle-Based Moral Judgement. Ethical Theory and Moral Practice, 16(2), 339-354.

Aleksandrova, S. (2008). Survey on the experience in ethical decision-making and attitude of Pleven. Medicine, Health Care and Philosophy, 11, 35-42.

Barnett, M. A., McMinimy, V., Flouer, G., \& Masbad, I. (1987). Adolescents' evaluations of peers' motives for helping. Journal of Youth and Adolescence, 16(6), 579-586.

Bebeau, M.J., Monson, V.E. (2014). A theoretical and Evidence-Based Approach for Designing Professional Ethics Education. W: L. Nucci, D. Narvaez, T. Krettenauer (eds.), Handbook of Moral and Character Education (507-534). New York: Routledge.

Białołęcka, E., Giryński, A. (1976). Próba oceny stosunku dzieci upośledzonych umysłowo do normy moralnej „Nie kradnij”. [An Attempt at Evaluating the Attitude of Children With Intellectual Disability to the Moral Norm „Do not steal”], Kwartalnik Pedagogiczny, 2, 109-119. 
Bone, P. F., Corey, R. J. (2000). Packaging Ethics: Perceptual Differences among Packaging Professionals, Brand Managers and Ethically-interested Consumers. Journal of Business Ethics, 24, 3, 199-213.

Braun-Gałkowska, M. (1994). W tę samą stronę. [Going the Same Way/Direction], Warszawa: Wydawnictwo Krupski i S-ka.

Buchan, H. F. (2005). Ethical Decision Making in the Public Accounting Profession: An Extension of Ajzen's Theory of Planned Behavior. Journal of Business Ethics, 61, 2, 165-181.

Cole, D., Sirgy, M. J., Bird, M. M. (2000). How Do Managers Make Teleological Evaluations in Ethical Dilemmas? Testing Part of and Extending the Hunt-Vitell Model. Journal of Business Ethics, 26, 3, 259-269.

Czusz, A., Otrębski, W. (2013). Wrażliwość moralna wychowanka - możliwości pomiaru u osób z niepełnosprawnością umysłową. W: I. Jazukiewicz, E. Rojewska (red.), Sprawności moralne a rozwój moralny [The Moral Sensitivity of the Charge - Measuring It in Persons with Intellectual Disability [in:]: I. Jazukiewicz, E. Rojewska (eds), Moral abilities and Moral Development] (62-102). Szczecin: Uniwersytet Szczeciński.

Davis, M. H. (1999). Empatia. Gdańsk: Gdańskie Wydawnictwo Psychologiczne.

Farber, P., Metro-Roland, D. (2021). Moral Education and Technology. Oxford Research Encyclopedia of $\begin{array}{llll}\text { Education. (Retrieved } 23 & \text { Dec. } & \text { from }\end{array}$ https://oxfordre.com/education/view/10.1093/acrefore/9780190264093.001.0001/acrefore$\underline{9780190264093-\mathrm{e}-24)}$

Frisancho, S., Delgado, G. E. (2018). Moral education as intercultural moral education. Intercultural Education, 29:1, 18-39, DOI: 10.1080/14675986.2017.1405214

Gała, A. (1992). Uwarunkowania wychowawcze dojrzałej moralności. [The Educational Determinants of Mature Morality], Lublin-Wrocław: Oficyna Wydawnicza „Lew”.

Gibson, K. L., Landwehr-Brown, M. (2009). Moral Development in Preparing Gifted Students for Global Citizenship. W: D. Ambrose, T. Cross (eds.), Morality, Ethics, and Gifted Minds (301-312). New York: Springer.

Gollwitzer, M., Schmitt, M., Schalke, R., Maes, J., Baer, A. (2005). Asymmetrical Effects of Justice Sensitivity Perspectives on Prosocial and Antisocial Behavior. Social Justice Research, 18, 2, 183-201.

Giryński A. (1976). Samoocena uczniów klas VIII szkół specjalnych [Self-assessment of 8th grade students of special schools]. Szkoła Specjalna, 3, 29-36.

Haji, I. (2010). Psychopathy, Ethical Perception, and Moral Culpability. Neuroethics, 3, 2, 135-150.

Heller, M., Życiński, J. (1980). Wszechświat i filozofia. Szkice z filozofii i historii nauki. Kraków: Polskie Towarzystwo Teologiczne.

Hernandez, J. (2011). The Changing Face of Ethics in the Workplace: Care and the Impact of Immigration Enforcement. Applying Care Ethics to Business, 3, 157-174.

Hojat, M. (2007). Empathy as Related to Sex, Personal Qualities, Clinical Competence, and Career Choice. W: M. Hojat (eds.), Empathy in Patient Care. Part II (141-161). New York: Springer. 
Hummels, H. (1999). Ethical challenges in a technological environment: The perspective of engineers versus managers. Science and Engineering Ethics, 5, 1, 55-72.

Jacobson, D. (2005). Seeing by Feeling: Virtues, Skills, and Moral Perception. Ethical Theory and Moral Practice, 8, 4, 387-409.

Jeong, C., Seok, J. (2021). Application of J. Haidt Moral Psychology Theory to Refine Moral Education Methods. Journal of Moral \& Ethics Education 72:1-27, DOI: 10.18338/kojmee.2021..72.1

Jing, Z., Suting, L. (2020). Research on Moral Education Affinity from the Perspective of Psychology. Ethics In Progress, 11(1), 120-132. https://doi.org/10.14746/eip.2020.1.7

Kościelska, M. (1984). Upośledzenie umysłowe a rozwój społeczny. [Intellectual Disability and Social Development], Warszawa: PWN.

Kostrzewski, J. (1981). Charakterystyka osób upośledzonych umysłowo. W: K. Kirejczyk (red.), Upośledzenie umysłowe. [The Characterisation of Persons with Intellectual Disability. [in:] K. Kirejczyk (ed.), Intellectual Disability] Pedagogika (97-129). Warszawa: PWN.

Lovecky, D. V. (2009). Moral Sensitivity in Young Gifted Children. W: D. Ambrose, T. Cross (eds.), Morality, Ethics, and Gifted Minds (161-176). Dordrecht: Springer.

Łukaszewski, W. (2007). Psychologiczne koncepcje człowieka. W: J. Strelau (red.), Psychologia. Podręcznik akademicki, Tom 1. [The Psychological Concepts of the Human. [in:] J. Strelau (ed.), Psychology. An Academic Textbook. Vol. 1], (67-92). Gdańsk: GWP.

Magda-Adamowicz, M., Szmalec, J. (2003). Wrażliwość moralna dzieci w wieku 7-10 lat prawidłowo rozwiniętych i upośledzonych umysłowo w stopniu lekkim. [Moral Sensitivity of Healthy Children Aged 7-10 Years and Those with Mild Intellectual Disability] Rocznik Lubuski, t. XXIX, cz. II, 103114.

Magda, M. (1999). Kształtowanie wrażliwości moralnej 10-11-latków. W: W. Kojs, R. Mrózka, R. Studenski (red.), Młodzież w sytuacjach zmian gospodarczych, edukacyjnych, społecznych i kulturowych [Shaping the Moral Sensitivity of 10-11-year olds. [in:] W. Kojs, R. Mrózka, R. Studenski (eds), Adolescents in the Face of Economic, Educational, Social and Cultural Changes] (33-43). Cieszyn: Wyd. UŚ.

Magda, M. (2000). Kształtowanie wrażliwości moralnej uczniów edukacji wczesnoszkolnej. [....] Toruń: Adam Marszałek.

Mitty, E. L. (2010). Ethical Decision Making. W: M. D. Foreman, K. Milise, T. T. Fulmer (eds.), Critical Care Nursing of Older Adults: Best Practices (83-100). New York: Springer Publishing Company.

Otrębski, W., Sudoł, A. (2020). Development and validation of the Moral Sensitivity Inventory for people with intellectual disabilities. Journal of Intellectual Disabilities, November, doi: $10.1177 / 1744629520962622$

Oumlil, A. B., Balloun, J. L. (2009). Ethical Decision-Making Differences Between American and Moroccan Manager. Journal of Business Ethics, 84, 4, 457-478. 
Pilecki, J. (1985). Kształtowanie się ocen moralnych upośledzonych umysłowo w stopniu lekkim uczniów klas V-VII. [The Evolution of Moral Sensitivity in Children with Mild Intellectual Disability in Classes 1 Through 8], Psychologia Wychowawcza, 5, 551-560.

Rabins, M. J. (1998). Teaching engineering ethics to undergraduates: Why? What? How? Science and Engineering Ethics, 4, 3, 291-302.

Reimer, M. (2010). Moral Aspects of Psychiatric Diagnosis: the Cluster B Personality Disorders. Neuroethics, 3, 2, 173-184.

Rest, J. R. (1994). Background: Theory and Research. W: J. Rest, D. Narvaez (eds.), Moral Development in the Professions (1-26). New York, London: Psychology Press.

Richards, T. A., Wrubel, J., Grant, J., Folkman, S. (2003). Subjective Experiences of Prayer Among Women Who Care for Children with HIV. Journal of Religion and Health, 42, 3, 201-219.

Roca, E. (2010). The Exercise of Moral Imagination in Stigmatized Work Groups. Journal of Business Ethics, $96,1,135-147$.

Roeper, A., Silverman, L. K. (2009). Giftedness and Moral Promise. W: T. Cross, D. Ambrose (eds.), Morality, Ethics, and Gifted Minds, (251-264). New York: Springer.

Roeser, S. (2012). Emotional Engineers: Toward Morally Responsible Design. Science and Engineering Ethics, $18,1,103-115$.

Rossouw, G. J. (1994). Rational interaction for moral sensitivity: A postmodern approach to moral decisionmaking in business. Journal of Business Ethics, 13, 1, 11-20.

Ruhe, J., Nahser, F. B. (2001). Putting American Pragmatism to Work in the Classroom. Journal of Business Ethics, 34, 3-4, 317-330.

Schalock, R. L., Borthwick-Duffy, S. A., Bradley, V. J. (2010). Intellectual Disability: Definition, Classification, and Systems of Supports. Washington: AAIDD.

Shawver, T. J., Sennetti, J. T. (2009). Measuring Ethical Sensitivity and Evaluation. Journal of Business Ethics, $88,4,663-678$.

Sparks, J. R., Merenski, J. P. (2000). Recognition-Based Measures of Ethical Sensitivity and Reformulated Cognitive Moral Development: An Examination and Evidence of Nomological Validity. Teaching Business Ethics, 4, 4, 359-377.

Starnawski, W. (2011). Bycie osobą. Podstawy moralności i wychowania. [Being Oneself. The Basics of Morality and Upbringing] Warszawa: Wydawnictwo Uniwersytetu Kardynała Stefana Wyszyńskiego.

Strous, R. D. (2012). History and its Relevance in the Development and Teaching of Research Ethics. W: J. Schildmann i in. (eds.), Human Medical Research. Ethical, Legal and Socio-Cultural Aspects (19-28). New York: Springer.

Szewczuk, W. (1972). Słownik psychologiczny. [The Psychological Dictionary], Warszawa: Wiedza Powszechna.

Tsvyk V.A., Tsvyk I.V. (2021). Moral education of students in the contemporary socjety. RUDN Journal of Sociology, 21, 2, 340-353. doi: 10.22363/2313-2272-2021-21-2-340-353 
Wimalasiri, J. S., Pavri, F., Jalil, A. A. K. (1996). An empirical study of moral reasoning among managers in Singapore. Journal of Business Ethics, 15, 12, 1331-1341.

Witkowski, T. (1967). Z badań nad wrażliwością moralną dzieci o obniżonej sprawności umysłowej. [Highlights from Research on Moral Sensitivity of Children with Lower Mental Ability.] Roczniki Filozoficzne, (4), 95-105.

Witkowski, T. (1994). Wrażliwość moralna dzieci o obniżonej sprawności umysłowej i sposób jej badania. [Moral Sensitivity of Children with Lower Mental Ability and the Method for Studying It.] Warszawa: MBDO.

Witkowski T., Otrębski W., Wiącek G., Czusz A. \& Mariańczyk K. (2015). Narzędzia pomiaru w psychologii rehabilitacji. Część I. Gdańsk: PTPiP.

Wong, M. (2020). University students' perceptions of learning of moral education: a response to lifelong moral education in higher education. Teaching in Higher Education, DOI: 10.1080/13562517.2020.1852201

Wyczesany, J. (2002). Pedagogika upośledzonych umysłowo. Wybrane zagadnienia. Kraków: Impuls.

You, D., Maeda, Y., Bebeau, M. J. (2011) Gender Differences in Moral Sensitivity: A Meta-Analysis, Ethics \& Behavior, 21,4, 263-282.

\section{Corresponding Author Contact Information:}

Author name: Wojciech Otrebski

Department: Institute of Psychology

Faculty: Social Sciences Faculty

University, Country: John Paul II Catholic University of Lublin, Poland

Email: otrebski@kul.pl

Please Cite: Otrebski, W., \& Czusz-Sudoł, A. (2022). Moral Sensitivity of Young People with Intellectual Disability - Its Role in The Process of Their Education. The European Educational Researcher, 5(1), 37-57. https://doi.org/10.31757/euer.512

Copyright: () 2022 EUER. This is an open-access article distributed under the terms of the Creative Commons Attribution License, which permits unrestricted use, distribution, and reproduction in any medium, provided the original author and source are credited.

Received: August 11, 2021 - Accepted: January 12, 2022 